How to cite: Boicu, D., Minea, I., Rusu, C., Jora, I. (2020) Hydrogeological Droughts Evaluation in North Eastern Part of Romania. 2020 "Air and Water-Components of the Environment" Conference Proceedings, Cluj-Napoca, Romania, p. 127-134, DOI: 10.24193/AWC2020_12.

\title{
HYDROGEOLOGICAL DROUGHTS EVALUATION IN NORTH EASTERN PART OF ROMANIA
}

\author{
Daniel BOICU ${ }^{1}$, Ionuț MINEA ${ }^{1}$, Constantin RUSU ${ }^{1,2}$, Ionuț JORA ${ }^{3}$
}

DOI: 10.24193/AWC2020_12

\begin{abstract}
Lack of rainfall in short time scales mainly affects soil moisture, whereas long-term rainfall deficit often affects streamflow and groundwater. The evolution of drought phenomena at all natural levels are analyzed selectively using different parameters. The evaluation of hydrogeological droughts was made for 7 hydrogeological wells developed on north-eastern part of Romania in the period between 1983 to 2018 . Hydrogeological droughts were analyzed using groundwater level duration curve (GLDC) and extracting the corresponding groundwater levels of the 90-percentile (GL90). The results show that the climatic conditions from the year 2012 have a major impact of hydrogeological droughts for entire regions. Also was observed an increase of hydrogeological droughts intensity for the groundwater level situated near the surface (1$2 \mathrm{~m}$ ) with effects on high variation of groundwater level and implications on management of water resources in the region.
\end{abstract}

Keywords: groundwater level, hydrogeological drought, indices, north-eastern Romania

\section{INTRODUCTION}

Due to the lack of an efficient observation system hydrogeological droughts are rarely analyzed in general studies that evaluate the impact of this natural phenomenon on the environment. Most often the decrease of groundwater level it was rather associated with the over-exploitation of groundwater, rather than as a result of climatic variations (Khalaj et al., 2019). On the other hand, the lack of data that objectively reflects the evolution of this phenomenon underground, has led to the indirect analysis of hydrogeological droughts through a series of variables such as: base flow and recession indices (Tallaksen, van Lannen 2004, Beck et al., 2013). In the last decades studies have appeared that directly analyze the hydrogeological droughts from the perspective of the impact brought on the way of the groundwater resources management (Lloyd, 2007) and the effect of climate changes on the

\footnotetext{
1 "Alexandru Ioan Cuza" University of Iași, Romania, Faculty of Geography and Geology, e-mail: boicu.d.daniel@gmail.com

${ }^{2}$ Romanian Academy, Iasi Branch

${ }^{3}$ Prut-Bârlad Water Administration Branch
} 
evolution of these resources (Minea, Croitoru 2015) and the loading capacity of aquifers in climatic drought conditions (Minea et al., 2012).

In the last decades Romania has been affected by frequent periods of atmospheric drought (Ioniță et al., 2016) with effects on river flow and recharge capacity of groundwater (Boicu et al., 2019). The impact of such phenomena can trigger a series of social problems that further aggravate the economic situation of some regions in the east and northeast of Romania included among the least developed at the level of the European Union. Over $50 \%$ of the population live in villages and most of them drawn water directly from the underground through wells. Take into account of these characteristics the main objective of this study is to analyze the hydrogeological droughts in a poorly monitored area and to apply specific methodologies to evaluate this phenomenon.

\section{DATA AND METHODS}

\subsection{Data used}

Taking into account the specific climatic characteristics of the Romanian territory in order to highlight the hydrogeological droughts, data were obtained from the Prut Bârlad Basin Water Administration from 7 hydrogeological wells located in the central-southern part of the Moldavian Plain. (Fig. 1).

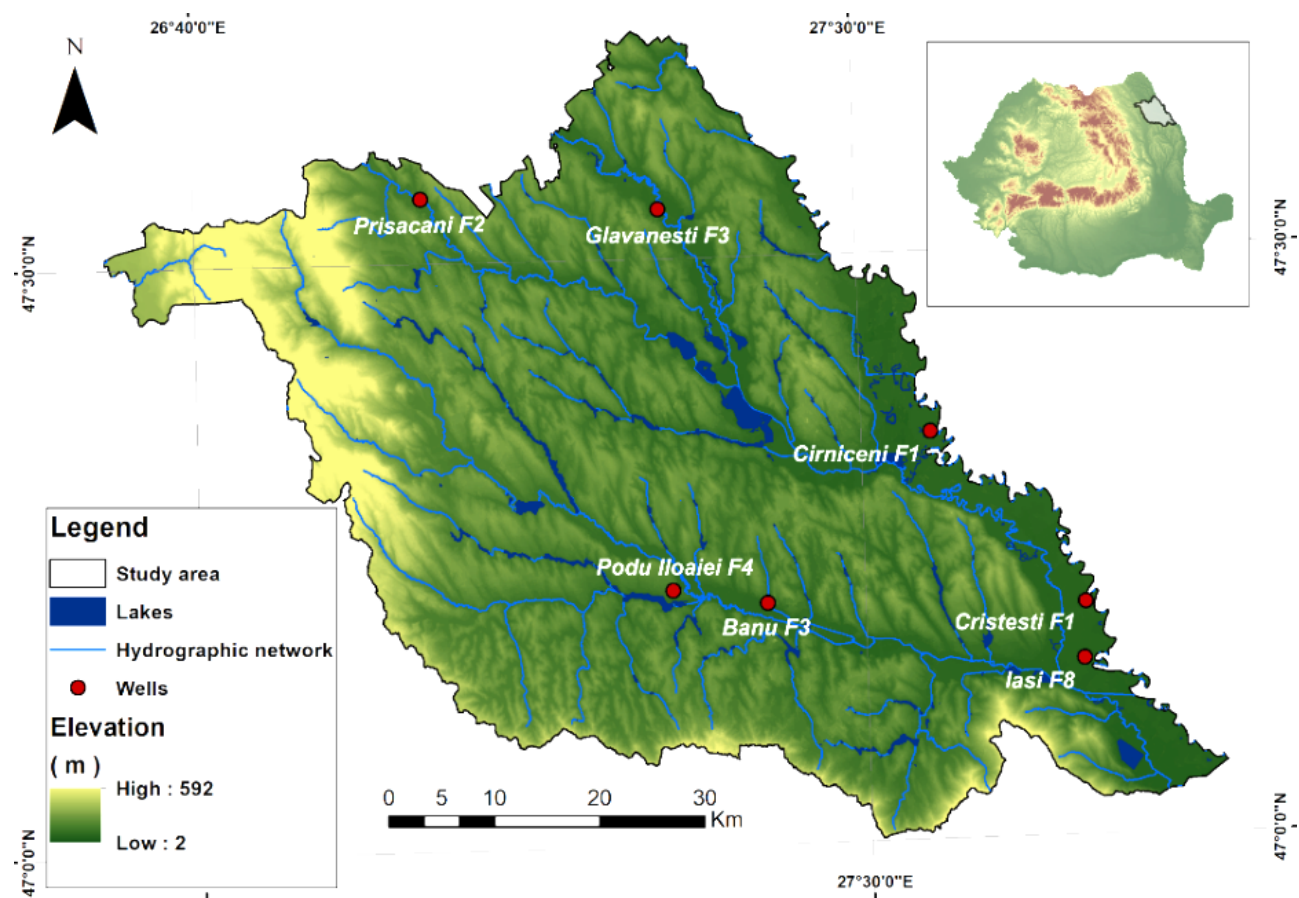

Fig. 1. Hydrogeologic welss analysed in central and central part of Moldavian Plain 
The data series include monthly average values of measurements on the groundwater level for the period between 1983 and 2017. These monthly average values were used to calculate the seasonal and annual average values and to extract the extreme values of the groundwater level variation.

\subsection{Methodology}

From the methodological point of view the first step in the analysis of hydrogeological droughts is to identify the thresholds from which this phenomenon manifests. In this case it can be used thereslod level method based on the analysis of the entire data string for each hydrogeological well. From groundwater level duration curve (GLDC) the values corresponding to certain thresholds considered characteristic are extracted (van Loon, 2015). In this paper, the corresponding groundwater levels of 90 percentile $\left(\mathrm{GL}_{90}\right)$ were used.

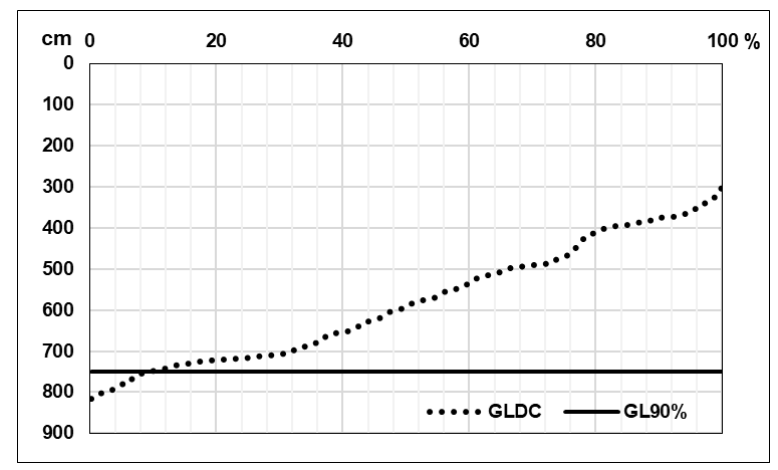

Fig. 2. Extraction of the corresponding 90-percentile groundwater levels (GL $\left.L_{90}\right)$ from GLDC (from hydrogeoloycal well F5 Podu Iloaiei)

To highlight the intensity of hydrogeological droughts, the formulas associated with the determination of the annual hydrogeological balance can be used (Panaitescu, 2008, Minea et al., 2019):

$$
\mathrm{W}=\mathrm{U}+\mathrm{E} \pm \Delta \mathrm{hr}
$$

where: $\mathrm{W}$ - annual rainfall supply (in meters);

$\mathrm{U}$ - annual thickness of groundwater resources (in meters);

$\mathrm{E}$ - evaporation from the groundwater level (in meters)

$\pm \Delta \mathrm{hr}$ - increasing or decreasing natural reserves (in meters).

For the determination of parameter $\mathrm{U}$, a period is analyzed in which the variations of the groundwater level are approximately constant (without strong infiltration and accelerated evaporation):

$$
U=\frac{H L_{t 1}-H L_{t 0} * H m}{\Delta t * h m} * T
$$


where: $\mathrm{HL}_{\mathrm{t} 0}$ and $\mathrm{HL}_{\mathrm{t} 1}$-groundwater level at the beginning and end of the chosen period $(\mathrm{m})$;

$\mathrm{Hm}$ - the average annual amplitude of the groundwater level (in meters);

$\mathrm{hm}$ - the average amplitude of the groundwater level during the analyzed period (in meters);

$\Delta \mathrm{t}-$ duration in days of the chosen period;

$\mathrm{T}-$ the number of days in a year.

Increasing or decreasing natural reserves ( $( \pm \Delta \mathrm{hr})$ is evaluated by the difference between the groundwater level recorded at the end $\left(\mathrm{HL}_{\mathrm{t} 1}\right)$ and at the beginning of the period analysis $\left(\mathrm{HL}_{\mathrm{t} 0}\right)$.

Evaporation values can be estimated by the difference between the amount of water dropped at the surface level (W) and the water found in the underground (U) to which is added the difference between the losses and the increase of the natural reserves $( \pm \Delta \mathrm{hr})$ :

$$
\mathrm{E}=\mathrm{W}-(\mathrm{U} \pm \Delta \mathrm{hr})
$$

Applying the two methodologies first the periods with values of the groundwater level below 90-percentile $\left(\mathrm{GL}_{90}\right)$ were identified and then the hydrogeological balance elements were calculated to see their intensity.

\section{RESULTS AND DISCUSSIONS}

The relations between the groundwater and the surface water it is supposed to be very difficult to analysed. The appearance of the hydrogeological droughts results from several external factors that can lead to important changes in the variation of the groundwater level. Often an atmospheric drought is not reflected underground, so identifying a period of hydrogeological deficit becomes very difficult.

From the analysis of the data on the variation of the groundwater level at the 7 hydrogeological stations and the application of GLDC medology, it is clear that from the whole number of years some have been identified when the decreases of the groundwater level were accentuated. Of these the years 1990, 2000, 2012; and 2017 have been proven in all cases as years with very high low groundwater values. In order to analyze the intensity of the hydrogeological droughts, the year 2012 was analyzed, when at $50 \%$ of the wells the highest values of the annual and monthly averages were recorded (Table 1).

Firstly, the values corresponding to the precipitation quantities (W) for the analyzed area were extracted (Dumitrescu, Bîrsan, 2015). For the central and southern part of the Moldavian Plain the average annual values of precipitation, for the year 2012 vary between $0.51 \mathrm{~m}$ at the Iasi hydrometric station and $0.45 \mathrm{~m}$ in the Glăvănești area. 
Table 1. The years in which hydrogeological droughts were recorded at the analyzed wells

\begin{tabular}{|c|c|c|c|c|c|}
\hline $\begin{array}{l}\text { Hydrogeological } \\
\text { well }\end{array}$ & $\begin{array}{c}\text { Years with } \\
\text { hydrogeological } \\
\text { drought } \\
\text { identified by the } \\
\text { GLDC method }\end{array}$ & $\begin{array}{c}\text { Year with the } \\
\text { highest annual } \\
\text { average values } \\
\text { of the } \\
\text { groundwater } \\
\text { level }\end{array}$ & $\begin{array}{l}\text { Maximum } \\
\text { annual } \\
\text { average value } \\
\text { of the } \\
\text { groundwater } \\
\text { level }(\mathrm{m})\end{array}$ & $\begin{array}{c}\text { Multiannual } \\
\text { mean values } \\
\text { of the } \\
\text { groundwater } \\
\text { level } \\
(1983-2017)\end{array}$ & $\begin{array}{c}\mathrm{GL}_{90} \\
(\mathrm{~m})\end{array}$ \\
\hline Iasi F8 & $\begin{array}{c}1990,1994, \\
1995,2000, \\
2004,2011- \\
2014,2016, \\
2017 \\
\end{array}$ & 2012 & 5.68 & 4.73 & 5.45 \\
\hline Banu F3 & 2011,2012 & 2012 & 5.90 & 5.34 & 5.80 \\
\hline Cristești F1 & $\begin{array}{c}1990,1994, \\
2011-2017\end{array}$ & 2016 & 5.89 & 4.95 & 5.72 \\
\hline Podu Iloaiei F4 & $\begin{array}{c}1994,2012, \\
2016 \\
\end{array}$ & 2012 & 1.48 & 1.04 & 1.35 \\
\hline Cîrniceni F1 & $\begin{array}{l}1990,2012, \\
2015-2017\end{array}$ & 2016 & 5.79 & 4.80 & 5.58 \\
\hline Glăvănești F3 & $\begin{array}{c}1990,1994, \\
1995,2011- \\
2017\end{array}$ & 2016 & 4.96 & 4.09 & 4.82 \\
\hline Prisacani F2 & $\begin{array}{c}1983,1990, \\
\text { 1995, 2004, } \\
\text { 2012, 2016, } \\
2017 \\
\end{array}$ & 1990 & 2.89 & 2.16 & 2.74 \\
\hline
\end{tabular}

In order to identify the impact of the decrease of the average monthly quantities of the atmospheric precipitations on the water supply of the groundwater for each drilling, a graph was shown which shows a marked decrease of the water supply from the surface to the ground (Figure 3). The analyzed period according to this graph was for June, July and August, when the drought intensity was highest.

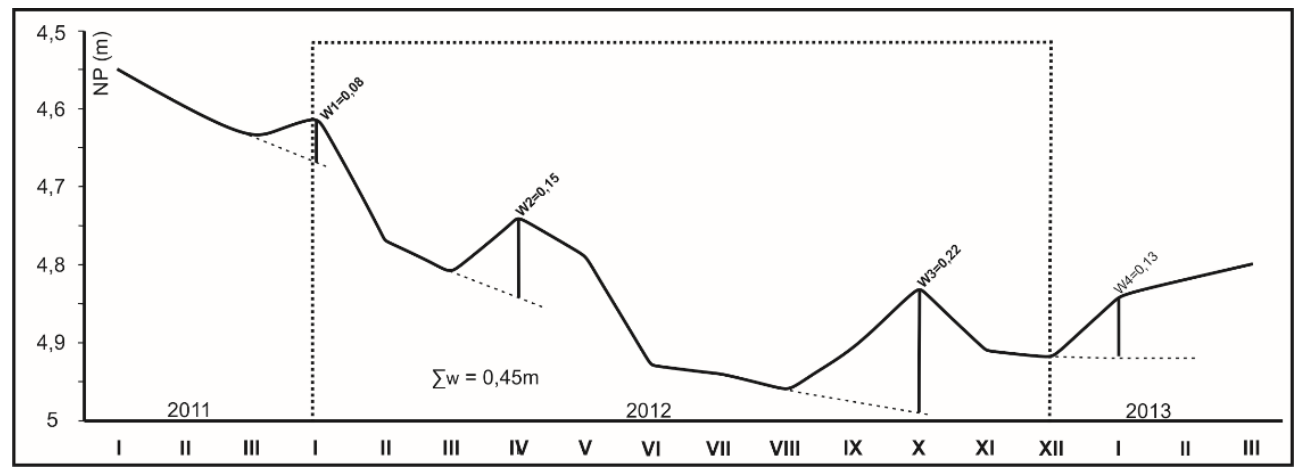

Fig. 3. Determination of the surface supply (W) using the graph of variation of the monthly average of groundwater level for the hydrogeological well F3 Glăvănești 
Based on this analysis and the associated formulas, the main parameters that show the intensity of the hydrogeological droughts at all 7 wells have been identified (Table 2).

The differences between the groundwater levels measured at the beginning of the period of hydrogeological drought and its end ranged between $0.12 \mathrm{~m}$ at F3 Glăvănești well to $0.48 \mathrm{~m}$ at F4 Podu Iloaiei well. These differences are reflected in values of the average annual thickness of the groundwater layer (U), which in the case of the F1 Glăvănești well reaches $0.48 \mathrm{~m}$ and the F4 Podu Iloaiei well reaches values of $0.98 \mathrm{~m}$. To explain these differences, the local hydrogeological conditions and the depth of the aquifer layers must be taken into account.

\section{Table 2. Groundwater balance elements estiamted for the hydrogeological wells in the year 2012}

\begin{tabular}{|c|c|c|c|c|c|c|c|c|c|}
\hline Drill & $\mathbf{\Delta t}$ & $\mathbf{H L}_{\mathbf{t}}$ & $\mathbf{H L}_{\mathbf{t 1}}$ & $\mathbf{\pm \Delta \mathbf { h r }}$ & $\mathbf{h m}$ & $\mathbf{H m}$ & $\mathbf{U}$ & $\mathbf{W}$ & $\mathbf{E}$ \\
\hline Iasi F8 & 92 & 5,65 & 5,91 & $-0,26$ & 0,09 & 0,05 & 0,57 & 0,51 & 0,20 \\
\hline Banu F3 & 92 & 5,71 & 6,10 & $-0,39$ & 0,13 & 0,07 & 0,83 & 0,51 & 0,04 \\
\hline Cristești F1 & 92 & 5,63 & 5,97 & $-0,34$ & 0,11 & 0,06 & 0,74 & 0,49 & 0,09 \\
\hline Podu Iloaiei F4 & 92 & 1,24 & 1,76 & $-0,48$ & 0,16 & 0,08 & 0,95 & 0,49 & 0,02 \\
\hline Cîrniceni F1 & 92 & 5,42 & 5,61 & $-0,19$ & 0,06 & 0,04 & 0,50 & 0,48 & 0,17 \\
\hline Glăvănești F3 & 92 & 4,52 & 4,64 & $-0,12$ & 0,04 & 0,04 & 0,48 & 0,45 & 0,09 \\
\hline Prisacani F2 & 92 & 2,50 & 2,80 & $-0,30$ & 0,10 & 0,07 & 0,84 & 0,48 & 0,06 \\
\hline
\end{tabular}

In the case of the F4 Podu Iloaiei well, the average depth of the groundwater level is about $1 \mathrm{~m}$, and the influences of the climatic elements (precipitation and temperature) are fully felt. The same situation is in the case of the F2 Prisacani well where the average annual depth of the groundwater level of $2.1 \mathrm{~m}$ does not impose important restrictions on the influence of the climatic elements. For wells with higher depths of the groundwater level, the influences of the climatic elements are significantly reduced. At greater depths of the groundwater level of over 4 or 5 meters an important role is acquired by the hydrogeological structure and the local influences in the groundwater-water relationship (Minea et al., 2012).

\section{CONCLUSIONS}

Some important conclusions with practical character can be drawn from the analysis carried out. Firstly, the assessment of hydrogeological droughts must be based on a clear and efficient scientific analysis system. Therefore we consider that the use of groundwater level duration curves (GLDC) and the extraction of the corresponding groundwater levels for the 90-percentile (GL90) can be an important starting point in the analysis of these processes. The assessment of the intensity of the hydrogeological droughts can be done by identifying the balance elements of the 
groundwater that for the southern and central part of the Moldavian Plain highlighted the following:

- the hydrogeological wells located at reduced depths are strongly influenced by the climatic elements (precipitation and temperature), the intensity of the processes associated with hydrogeological droughts being much accentuated;

- at depths greater than 4-5 m of the groundwater level, the influence of the climatic elements is reduced, but in the conditions of the persistence of hydrological drought at surface level, as was the case of June, July and August from 2012, the water deficit reflected in decreases of the groundwater level.

Given the increasing frequency of atmospheric drought phenomena, their impact will have an impact on the variation of the groundwater level with an effect on reducing groundwater reserves and its utilization.

\section{REFERENCES}

1. Beck, H.E., van Dijk, A.I.J.M., Miralles, D.G., de Jeu, R.A.M., Bruijnzeel, L.A., McVicar, T.R., and Schellekens, J. (2013), Global patterns in base flow index and recession based on streamflow observations from 3394 catchments, Water Resour. Res., 49, 7843- 7863, doi:10.1002/2013WR013918.

2. Boicu, D., Minea, I., Chelariu, O.E., Iosub, M. (2019), Evaluation on groundwater recharges capacity using AHP method. Case study: The Moldavian Plain, Aerul şi apa componente ale mediului, 181-188.

3. Dumitrescu, A., Bîrsan, M.V. (2015), ROCADA: A gridded daily climatic dataset over Romania (1961-2013) for nine meteorological variables. Natural Hazards, 78, 1045-1063.

4. Ionita, M., Scholz, P., Chelcea, S. (2016), Assessment of droughts in Romania using the Standardized Precipitation Index. Nat Hazards 81, 1483-1498. https://doi.org/10.1007/s11069-015-2141-8

5. Lloyd, J.W (2007), The difficulties of regional groundwater resources assessments in arid areas, Arab J Sci Eng. 32:35-47.

6. Khalaj, M., Kholghi, M., Sagrafian, B., Bazrafshan, J. (2019), Impact of climate variation and human activities on groundwater quality in northwest of Iran, Journal of Water Supply: Research and Technology-Aqua 68 (2): 121-135.

7. Minea, I., Butelcă, D., Niacşu, L. (2012), Modele de variaţie a nivelului freatic în condiţii de secetă. Studiu de caz bazinul superior al Bârladului, Geographia Napocensis, $75-82$ (in Romanian).

8. Minea, I., Croitoru, A.E. (2015), Climate Changes and their impact on the variation of groundwater level in the Moldavian Plateau (Eastern Romania), International Multidisciplinary Scientific Geoconferences, SGEM 2015, Conference Proceedings, Vol I, Hydrology and Water Resources, 137-145.

9. Minea, I., Chelariu, O.E., Iosub, M., Boicu, D. (2019), Hidrologia mediilor continentale. Aplicații practice 2.0, Edit. Transversal, Târgoviște.

10. Panaitescu, E.V. (2007), Acviferul freatic şi de adâncime din bazinul hidrografic Bârlad, Casa Editorială Demiurg, Iași.

11. Pravălie, R., Piticar, A., Rosca, B., Sfíca, L., Bandoc, G., Tiscovschi, A., Patriche, C. (2019), Spatio-temporal changes of the climatic water balance in Romania as a 
response to precipitation and reference evapotranspiration trends during, 19612013. Catena, 172, 295-312.

12. Tallaksen, L.M., van Lannen, H.A.J. (2004), Hydrologycal drought. Processes and estimation methods for streamflow and groundwater, Elsevier, $579 \mathrm{pp}$.

13. van Loon, A.F. (2015), Hydrological drought explained, WIREs Water, 2:359-392. 